\title{
Keanekaragaman Jenis Herpetofauna di Kawasan Ekowisata Goa Kiskendo, Kulonprogo, Provinsi Daerah Istimewa Yogyakarta
}

\author{
Species Diversity of Herpetofauna in Kiskendo Cave Ecotourism Area, Kulonprogo, \\ Daerah Istimewa Yogyakarta Province
}

\author{
Tony Febri Qurniawan ${ }^{1}$ dan Rury Eprilurahman ${ }^{2}$ \\ ${ }^{1}$ Kelompok Studi Herpetologi, Fakultas Biologi, Universitas Gadjah Mada Yogyakarta \\ Sekip Utara, Yogyakarta 55281 \\ ${ }^{2}$ Laboratorium Sistematika Hewan, Fakultas Biologi Universitas Gadjah Mada Yogyakarta \\ Sekip Utara, Yogyakarta 55281 \\ E-mail: tonie_kun@yahoo.com *Penulisuntukkorespondensi
}

\begin{abstract}
This research was aimed to figure out the diversity of herpetofauna in Kiskendo Cave ecotourism area, Jatimulyo District, Kulonprogo Regency, Daerah Istimewa Yogyakarta Province. During six months (November 2007-April 2008), nocturnal and diurnal surveys were administered in Kiskendo Cave ecotourism area. Total number of 42 species which consist of 29 species of reptiles and 13 amphibians were recorded. They are belong to six families of frogs, four families of lizard and five families of snake. On all of identified species, only two (Limnonectes kuhlii and Michrohyla achatina) are endemic to Java. Based on the current study, Kiskendo Cave ecotourism area still has a good ecosystem conditions to support herpetofauna lives.
\end{abstract}

Keywords: Herpetofauna, diversity, Kiskendo Cave, ecotourism

\begin{abstract}
Abstrak
Perubahan ekosistem dan kondisi lingkungan sangat memengaruhi kehidupan herpetofauna (amfibi dan reptil). Salah satu wilayah yang diduga masih cukup layak untuk menunjang kehidupan herpetofauna adalah Kawasan Ekowisata Goa Kiskendo, Kulonprogo, Daerah Istimewa Yogyakarta. Penelitian tentang keanekaragaman jenis herpetofauna di daerah tersebut perlu dilakukan untuk mendapatkan informasi jumlah jenis dan sebarannya sebagai data awal keanekaragaman fauna. Penelitian dilaksanakan selama enam bulan (November 2007-April 2008) dengan metode pengamatan langsung baik siang maupun malam. Berdasarkan penelitian diperoleh 42 jenis herpetofauna yang terdiri atas 29 jenis reptil dan 13 jenis amfibi. Reptil yang diperoleh terdiri atas kadal (empat suku) dan ular (lima suku), sedangkan untuk amfibi terdiri dari enam suku. Dua jenis amfibi (Limnonectes kuhlii dan Michrohyla achatina) diketahui merupakan jenis endemik Pulau Jawa. Berdasarkan penelitian ini dapat disimpulkan bahwa kondisi ekosistem di kawasan wisata Goa Kiskendo masih cukup bagus sebagai habitat herpetofauna.
\end{abstract}

Kata kunci: Herpetofauna, keanekaragaman, Goa Kiskendo, ekowisata 